\title{
PLASMINOGEN AND ITS FRAGMENTS IN RAT BRAIN: A PLAUSIBLE ROLE FOR ASTROCYTES IN ANGIOSTATIN GENERATION
}

\author{
A. A. TYKHOMYROV , V. S. NEDZVETSKY $Y^{2,3}$, C. A. A $\breve{G} C A^{3}$, \\ V. V. KORSA ${ }^{1}, T$. V. GRINENKO \\ ${ }^{1}$ Palladin Institute of Biochemistry, National Academy of Sciences of Ukraine, Kyiv; \\ ${ }^{2}$ Dnipropetrovsk National University, Dnipro, Ukraine; \\ ${ }^{3}$ Bingöl University, Bingöl, Turkey; \\ e-mail: artem_tykhomyrov@ukr.net
}

The purpose of the present study was to examine the plasminogen localization and to detect levels of its fragments (angiostatins) in various regions of rat brain as well as to establish whether rat brain astrocytes could be involved in angiostatin production. It was shown immunohistochemically that plasminogen is distributed broadly in the various brain regions, with predominant expression in meningeal layer and IV, $V$, and VI layers or cerebral cortex, dentate gyrus, meningeal and Purkinje cells, molecular and granular layers of cerebellum, as well as vessel walls. Angiostatin polypeptides were detected by Western blot analysis mostly in the cerebral cortex and were represented by 50 and 40-30 kDa polypeptides. In the whole cell lysates from primary cultures of rat astrocytes, immunoreactive polypeptides with $M_{m} \sim 92,84,65-60,50,40,38-30 \mathrm{kDa}$, corresponding to native plasminogen and a variety of its truncated products, including angiostatin polypeptides, were revealed. Incubation of astrocytes with exogenous plasminogen resulted in gradual increasing levels of some plasminogen fragments, particularly $30 \mathrm{kDa}$ protein. Moreover, this polypeptide appeared to be the single angiostatin released by astrocytes in vitro. We report here for the first time that astrocytes are one of the cell types in CNS that could be responsible for angiostatin formation and releasing.

Key words: plasminogen, angiostatins, rat brain, astrocytes, primary culture, immunohistochemistry, Western blot.

$\mathrm{T}$ he plasminogen/plasmin (Pg/Pm) system includes catalytically inactive proenzyme (Pg), which can be converted by Pg activators (PAs) into active serine proteinase (Pm), and specific PA inhibitors. Structurally Pg contains some unique domains, such as a secretion signal peptide, a preactivation domain, an activatable serine proteinase domain, and five triply-looped disulphide-bonded domains (K1-K5) called kringles. The kringles act in concert to facilitate both proteolytic and nonproteolytic events such as maintaining the conformation of Glu-Pg so that it is resistant to inappropriate activation, binding to surfaces (clots and cell membranes). $\mathrm{Pg} / \mathrm{Pm}$ system has rather ubiquitous nature in an organism. The relative abundance of Pg as well as PAs and their cell receptors in different tissues indicates a potential regulatory role of this system in the extracellular events requiring proteolysis or controlling cellular activity, beyond the role of these proteins in the fibrinolytic pathway [1]. Substantial evidences have established that proteins of $\mathrm{Pg} / \mathrm{Pm}$ system are responsible for many important functions within a brain [2]. For example, tissue-type PA (t-PA) is able to modulate permeability of blood-brain barrier (BBB) and exacerbate injury in ischemic stroke. Pm generated on the cell surface modulates the astrocytic cytoskeleton and downstream signaling in astrocytes via the Rho/Rho kinase (ROCK) pathway [3]. It has been established that $\mathrm{Pg} / \mathrm{Pm}$ system participates in synaptic plasticity, neurite outgrowth, and migration of granule cells during cerebellum development $[4,5]$.

(C) 2017 Tykhomyrov A. A. et al. This is an open-access article distributed under the terms of the Creative Commons Attribution License, which permits unrestricted use, distribution, and reproduction in any medium, provided the original author and source are credited. 
Though the main proteins of this system have been shown to be closely involved in regulation of many processes in central nervous system (CNS), of equal interest is the inquiry of functional significance of proteolytic fragments of $\mathrm{Pg} / \mathrm{Pm}$, referred to as angiostatins, in the CNS. The first angiostatin has been first isolated from mice bearing a Lewis lung carcinoma and has been shown to be produced by cells of primary tumors. It has been well-documented that angiostatins induce anoikis and apoptosis and inhibit proliferation and migration of endotheliocytes, thus restrict vessel tube formation and neovascularization $[6,7]$. Currently, numerous reports indicate that various cell types are able to generate angiostatins in relatively high amounts $[8,9]$. In the previous papers, angiostatins are described as constantly formed by several types of retina-resident cells [10]. So far, studies of angiostatins in brain tissue have been limited, with few exceptions [11-13], to effects of angiostatin-encoding genetic engineering constructions, which are expressed in the models of rat and human glioma cells developed for testing anti-angiogenic strategy for malignant brain tumor therapy $[14,15]$.

Astrocytes are the most abundant cellular type in the brain, where they fulfil many vital functions [16]. Several lines of investigation show that astrocytes play a regulatory role for endothelial functions. Perivascular astrocytes are thought to control the induction and maintenance of endothelial BBB phenotype [17]. Astrocytes participate directly and actively in capillary formation in the brain. Astrocyte-mediated control of angiogenesis is realized through the maintenance of physiological balance of angiogenic and angiostatic factors, which is altered as a result of ischemia, inflammation, injury or tumor growth [18]. However, contribution of astroglia to angiostatin formation in CNS is still unexplored. From these circumstances, understanding of mechanisms that control brain angiogenesis is critical for targeting various pathological conditions, in which aberrant vessel growth plays a key role.

Earlier, astrocytes have been highlighted as inductors of endothelial activation and vessel formation due to their ability to synthesize the most potent and specific growth factor for endotheliocytes (vascular endothelial growth factor, VEGF). Nevertheless, it has been established that retinal astrocytes are able to counteract pro-angiogenic stimuli through releasing of exosomes loaded with angio-suppressors, i.e. endostatin and pigment-endothelium derived fac- tor (PEDF) [19]. Meanwhile, astrocytes appeared to be capable of producing and secreting proteolytically active matrix metalloproteinases (MMP) and Pm, representing proteinases responsible for Pg cleavage and angiostatin formation [20]. There is no information in the literature concerning ability of astrocytes to mediate proteolityc degradation of Pg resulting in angiostatin production. Studying of the localization of angiostatins as well as their precursor protein in the rat brain and identification of angiostatin-producing cell types in the rat CNS is of significant importance because these rodents are commonly used for modeling human neurodegenerative disease conditions.

Thus, the aim of the current study was to examine the localization of Pg and to detect angiostatin levels in various regions of the rat brain as well as to establish whether rat brain astrocytes are able to produce angiostatins.

\section{Materials and Methods}

Reagents and antibodies. Bovine serum albumin (BSA), fetal bovine serum (FBS), protease and phosphatase inhibitor cocktail, ethylenediaminetetraacetic acid (EDTA), paraformaldehyde (PFA), ethylene glycol-bis( $\beta$-aminoethyl ether)-N,N,N',N'tetraacetic acid (EGTA), glycerol, Triton X-100, Tween-20, ammonium persulfate, tetramethylethylenediamine (TEMED), 2'-(4-hydroxyphenyl)-5-(4methyl-1-piperazinyl)-2,5'-bi-1H-benzimidazole trihydrochloride hydrate (Hoechst 33258), Ponceau S solution, RIPA buffer for protein extraction, Dulbecco's modified Eagle's medium (DMEM), acrylamide, bis-acrylamide, tris(hydroxymethyl)aminomethane, sodium phosphates, sodium chloride, luminol, coumaric acid, and hydrogen peroxide were purchased from Sigma (USA); glycine was purchased from Fisher Scientific (USA); sodium dodecyl sulphate (SDS) and methanol were from Merck (Germany); molecular weight markers (PageRuler Prestained Protein Ladder) were obtained from Fermentas (Germany); polyvinylidene difluoride (PVDF) membranes were purchased from Amersham Biotech (Sweden), radiographic films were from Konica Minolta Medical \& Graphic, Inc. (Japan), developer and fixer solutions were purchased from Kodak (USA). All other chemicals were of analytical reagent grade.

Pg from rat plasma was purified by affine chromatography on Lys-sepharose (GE Healthcare BioSciences, USA) as described in [21]. Isolated Pg was of electrophoretic purity and did not exhibit sponta- 
neous proteolytic activity. Pg whole molecule was used for rabbit immunization. Specific IgG from immune sera of rabbits were isolated by chromatography on immunoaffine angiostatin-conjugated sorbent. Polyclonal antibodies recognized homologous antigen epitopes in Pg fragments as well as the same determinants within the tertiary structure of the precursor protein. Rabbit anti-GFAP antibodies were purchased from Santa Cruz (USA). Secondary anti-rabbit horseradish peroxidise (HRP)-, fluorescein isothiocyanate (FITC)- or Alexa Fluor 594-conjugated IgG were purchased from Abcam (USA).

Animals and tissue preparation. Experiments were conducted with the use of six males of Wistar rats aged 8-10 weeks with an average weight 180220 g. Rats were subjected to a 12:12-h daylight/ darkness and allowed unlimited access to chow and water. All experimental procedures conformed to the Guidelines for Proper Control of Animal Experiments, minimizing the number of animals used and their suffering, and were approved by the local ethics regulations. After one week of acclimation, each rat was deeply anaesthetized and decapitated. The brains obtained from three randomly selected rats were immediately fixed in 4\% PFA in $50 \mathrm{mM}$ phosphate buffer (PBS), $\mathrm{pH} 7.0$, for $72 \mathrm{~h}$, transferred to $68 \%$ ethanol for $24 \mathrm{~h}$ at $4{ }^{\circ} \mathrm{C}$, and then embedded in paraffin wax. Brain sections prepared from the visual cortex region, hippocampus, and cerebellum were cut on a microslicer at a thickness of 5-7 $\mu \mathrm{m}$, and the resultant sections were washed in PBS and dried.

The rest three freshly isolated brains were used for protein extraction. Brain tissues prepared from cerebral cortex, hippocampus, and cerebellum were homogenized in ice-cold $25 \mathrm{mM}$ tris- $\mathrm{HCl}$ (pH 7.4) buffer, containing $0.15 \mathrm{M} \mathrm{NaCl}, 1 \%$ SDS, $2.5 \mathrm{mM}$ EDTA, $6.5 \mu \mathrm{M}$ aprotinin, $1.5 \mu \mathrm{M}$ pepstatin A, $23 \mu \mathrm{M}$ leupeptin, $1 \mathrm{mM}$ phenylmethylsulfonyl fluoride, $5 \mu \mathrm{g} / \mathrm{ml}$ soybean trypsin inhibitor, 1 $\mu \mathrm{M}$ sodium orthovanadate (tissue $:$ buffer $=1: 10$, $\mathrm{w} / \mathrm{v})$. The homogenates were sonicated three times for $60 \mathrm{sec}$ using ultrasonic disintegrator Sartorius (Labsonic ${ }^{\circledR}$ M, Göttingen, Germany) and centrifuged at $16,000 \mathrm{~g}$ for $60 \mathrm{~min}$ at $4{ }^{\circ} \mathrm{C}$. The resultant supernatants were discarded and transferred into clean plastic tubes, and protein concentration in each supernatant was determined spectrophotometrically in accordance with Stoscheck method [22]. The supernatants were diluted $1: 1$ in non-reducing Lae- mmli sample buffer (62.5 mM tris-HCl, $\mathrm{pH} 6.8,2 \%$ SDS, 25 glycerol, and $0.01 \%$ Bromophenol Blue) and boiled for $5 \mathrm{~min}$.

Primary culture of astrocytes. Primary astrocyte cell cultures were obtained from newborn rats as described in [23]. Briefly, cerebral hemispheres from 1- or 2-day-old Wistar rats were removed in cold PBS and dissociated mechanically with a syringe equipped with a 1-mm gauge needle, and filtered through a $100-\mu \mathrm{m}$ sieve (Falcon, Franklin Lakes, NJ, USA). Dissociated cells were resuspended in culture medium supplemented with $10 \%$ FBS. Astrocytes were seeded in $175-\mathrm{cm}^{2}$ flasks (Greiner Bio-one $\mathrm{GmbH}$, Frickenhausen, Germany) at a starting density $2 \times 10^{5}$ cells $/ \mathrm{ml}$ (or $20 \mathrm{ml} /$ flask) in DMEM supplemented with $10 \%(\mathrm{v} / \mathrm{v}) \mathrm{FBS}$ and incubated at $37{ }^{\circ} \mathrm{C}$ in atmosphere containing $5 \% \mathrm{CO}_{2}$. The cells were characterized morphologically and tested for expression of glial fibrillary acidic protein (GFAP), an astrocyte marker. The cells were then washed with PBS trice and detached from the plastic with the use of enzyme-free cell dissociation buffer. After the cells were centrifuged at $500 \mathrm{~g}$ for $5 \mathrm{~min}$, they were plated for the experiments in DMEM without FBS at density $3 \times 10^{5}$ cells $/ \mathrm{ml}$.

$P g$ fragmentation experiments. All experiments were performed on 11- to 12-day-old astrocyte cell cultures. Before adding Pg, medium for astrocytic cultures was replaced by FBS-free DMEM, and then $10 \mu \mathrm{g} / \mathrm{ml}$ of $\mathrm{Pg}$ (final concentration $0.11 \mu \mathrm{M}$ ) was added to the cells and incubated at $37^{\circ} \mathrm{C}$. Aliquots of conditioned medium were collected just before Pg addition and 20, 60, and 120 min after beginning of Pg treatment. After each time point, the cells were washed with PBS thrice, collected with scraper and placed into plastic Eppendorf tubes. The cells were centrifuged at $500 \mathrm{~g}$ for $10 \mathrm{~min}$ at $4{ }^{\circ} \mathrm{C}$. The pellets were resuspended with insulin syringe in the ice-cold RIPA buffer containing cocktail of inhibitors and centrifuged at $5000 \mathrm{~g}$ for $15 \mathrm{~min}$ at $4{ }^{\circ} \mathrm{C}$. The samples of conditioned medium and cell lysates were mixed with non-reducing Laemmli buffer and boiled for $5 \mathrm{~min}$. The volumes of conditioned medium loaded onto gel electrophoresis were adjusted to contain $0.25 \mu \mathrm{g}$ from the initial Pg concentration. Each sample of cell lysates prepared for gel electrophoresis contained $50 \mu \mathrm{g}$ of total protein.

Immunocytochemical and immunohistochemical assessments. Astrocytes on the glass-bottom dishes were fixed with $4 \%$ PFA (in PBS, containing 
$4 \%$ sucrose) for $25 \mathrm{~min}$ at room temperature and permeabilized with ice-cold $0.3 \%$ Triton X-100 in blocking buffer (20 mM PBS, $0.135 \mathrm{M} \mathrm{NaCl}, 16.7 \%$ fetal calf serum). After permeabilization procedure, cells were washed with PBS three times for 5 min each time. Non-specific binding was blocked by 30 min incubation with $5 \%$ BSA in PBS at $37^{\circ} \mathrm{C}$. Then, cells were incubated overnight at $4{ }^{\circ} \mathrm{C}$ with primary anti-GFAP (1:100). After that, cells were washed thrice with PBS for 5 min and incubated with secondary antibody anti-rabbit Alexa-Fluor 594-conjugated $\operatorname{IgG}(1: 200)$ for $1 \mathrm{~h}$ at room temperature in the dark. Cells were washed again five times with PBS for $5 \mathrm{~min}$ and observed under LSM510 confocal laser scanning microscope (Zeiss, Jena, Germany). Laser power and the detector settings were kept constant to maintain consistency in the data collection system. For visualization studies, 10 dishes were examined in random fields in at least three experiments.

For immunohistological staining, paraffin sections were gradually deparaffinised in xylene for 3 min twice, xylene-ethanol mixture $(1: 1)$, rehydrated in descending grades of ethanol (96, 75, and 50\%) $3 \mathrm{~min}$ each, and then brought to double distilled water for $5 \mathrm{~min}$. For antigen retrieval, sections were heated in microwave oven in $25 \mathrm{mM}$ tris$\mathrm{HCl}$ buffer, $\mathrm{pH} 7.4$, containing $5 \mathrm{mM}$ EDTA and $0.25 \%$ Triton X-100, for $1 \mathrm{~min}$ at $600 \mathrm{~W}$. Sections were rinsed with PBS, blocked in 3\% BSA for $1 \mathrm{~h}$ at $37^{\circ} \mathrm{C}$. After rinsing in PBS, sections were incubated with the primary anti-Pg antibodies $(1: 100)$ at
$4{ }^{\circ} \mathrm{C}$ overnight. Sections were rinsed with PBS trice, followed by $1 \mathrm{~h}$ incubation with secondary FITCconjugated antibody $(1: 250)$ at $37^{\circ} \mathrm{C}$. After rinsing the sections in PBS twice, the nuclei were counterstained with Hoechst $33258(1 \mu \mathrm{g} / \mathrm{ml}$ PBS $)$ for $5 \mathrm{~min}$ at room temperature, then thoroughly rinsed in PBS and double distilled water. Non-specific binding control slices were incubated without primary antibody. Immunolabeling and DNA staining were visualized by confocal laser scanning fluorescence microscopy, images were collected and analyzed using Zeiss ZEN 2009 Light Edition software.

Western blot. Equivalent amounts of proteins of conditioned medium of astrocytic primary culture, cell lysates and extracts from brain tissue were separated by denaturing electrophoresis in gels with $5-15 \%$ polyacrylamide gradient and electrotransferred onto PVDF membranes. The adequacy of protein loading was confirmed by staining with Ponceau S solution. The membranes were saturated with $3 \%$ BSA in $50 \mathrm{mM}$ tris-buffered saline (TBS) for $1 \mathrm{~h}$ at $37^{\circ} \mathrm{C}$ and incubated with the primary antiPg antibodies $(1: 2500)$ at $4{ }^{\circ} \mathrm{C}$ overnight. Blots were washed 5 times in TBS containing $0.1 \%$ Tween-20 (TBST) for 5 min to remove any unbounded antibody, and incubated with HRP-conjugated secondary antibody for $90 \mathrm{~min}$ at $37^{\circ} \mathrm{C}$. After incubation, membranes were washed in TBST for 5 min each. Immunoreactivity was developed by enhanced chemiluninescence with luminol $(0.25 \mathrm{M}$ luminol diluted in DMSO, 0.09 coumaric acid diluted

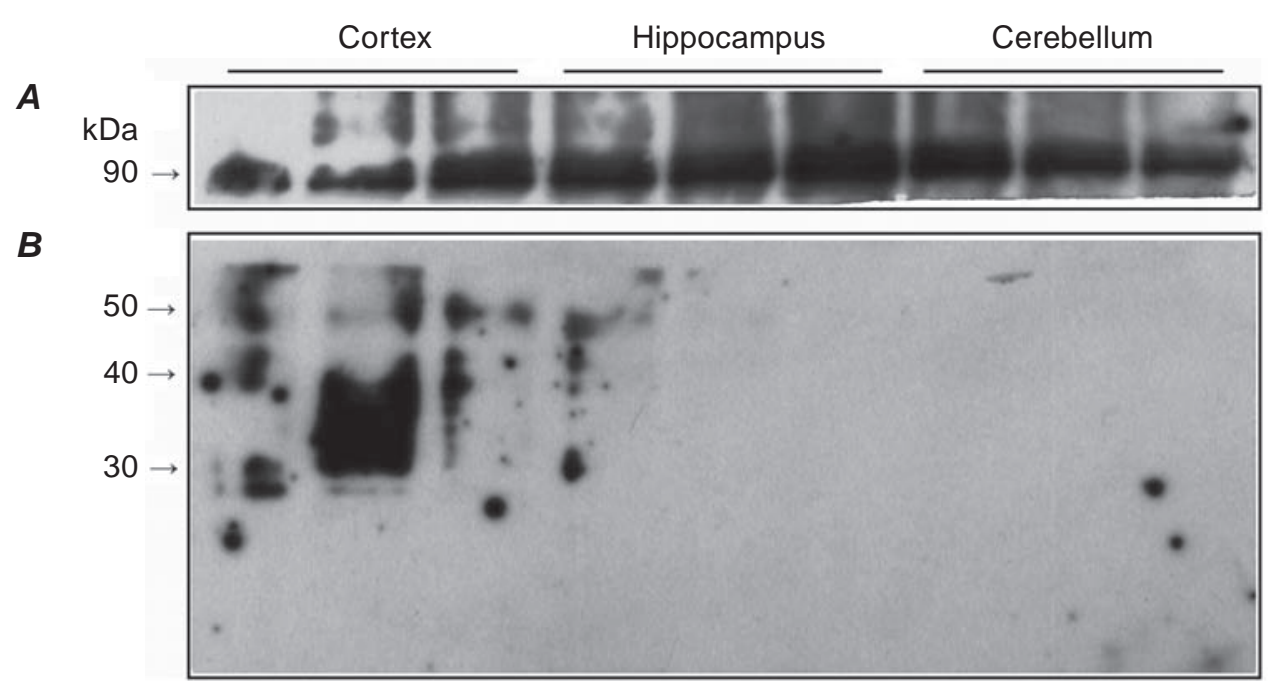

Fig. 1. Western blot of protein samples obtained from different regions of rat brain: $\boldsymbol{A}$ - plasminogen immunostaining; $\boldsymbol{B}$ - angiostatin immunostaining 
in DMSO, $0.1 \mathrm{M}$ tris $\mathrm{pH} 8.5$, and $0.0035 \% \mathrm{H}_{2} \mathrm{O}_{2}$ ) for $1 \mathrm{~min}$, and radiographic films were visualized with use of the Carestream medical X-ray processor (USA).

\section{Results and Discussion}

Immunoblotting of protein samples of the three rat brain regions revealed Pg-immunoreactive band of the approximate $\mathrm{M}_{\mathrm{m}} 90 \mathrm{kDa}$, which demonstrates the greater abundance in hippocampus in comparison with hemisphere cortex and cerebellum (Fig. 1).

In addition, we also observed further truncated immunoreactive polypeptides that migrated to a size of about $50 \mathrm{kDa}$ and 40-30 kDa. According to their molecular masses, these fragments could be considered as angiostatins K1-4 and K1-3, respectively. Among regions studied, the much greater abundance of angiostatins was shown in cerebral cortex.
The results of Western blot are confirmed by immunohistochemical analysis of brain section that evidently demonstrates Pg-positive immunostaining to be distributed broadly in distinct brain regions (Fig. 2). Control section of hippocampus stained with secondary antibodies alone did not show any fluorescence (Fig. 2, A). Confocal microscopic observations revealed $\mathrm{Pg}$ immunoreactivity in a frontal lobe of hemisphere (Fig. 2, B). In the cerebral cortex, the pronounced fluorescence was observed in meningeal layers and deep layers (IV, V, and VI), while no significant specific immunoreactivity was noted in the outer layers (I, II, III). Robust immunostaining for Pg was seen in hippocampus, and the most intensive fluorescence signal was obtained for dentate gyrus region (Fig. 2, C). In the cerebellum cortex, Pg immunostaining was found predominantly in meningeal cells and molecular layer (Fig. 2,D).
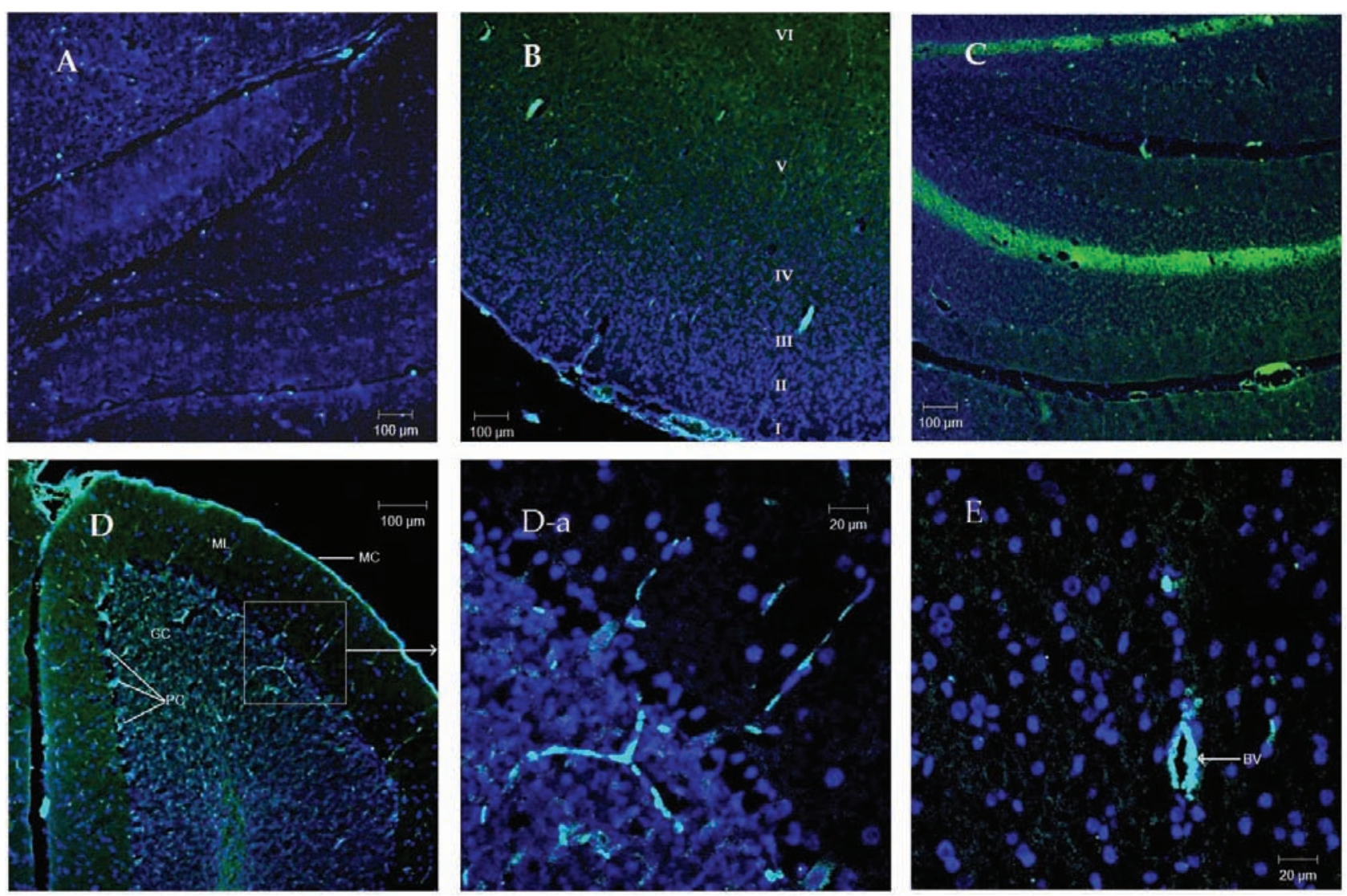

Fig. 2. Representative fluorescence micrographs of plasminogen immuno-labelling on paraffin-embedded sections of different regions of rat brain (green-plasminogen immunoreactivity, blue-nuclei): $\boldsymbol{A}$ - hippocampus (control for non-specific secondary antibody binding), $\boldsymbol{B}$ - frontal area of hemisphere, $\boldsymbol{C}$ - hippocampal area and dentate gyrus region, $\boldsymbol{D}$ - cerebellum, $\boldsymbol{D}$-a - higher magnification on the boxed area of cerebellum in $D$, $\boldsymbol{E}$ - blood vessel region. I - VI - cortex layers, MC - meningeal cells, ML - molecular layer, PC - Purkinje cells, GC-granular cell layer, BV-blood vessel 
We also observed abundant Pg-positive immunostaining in cerebellar Purkinje cells and its Mosaic dispersion in the cerebellar granular layer. Typical image of Pg subcellular localization is presented in Fig. $2(D-a)$. Pg immunoreactivity is demonstrated to fill extracellular matrix, cell somata and pericaryon area and also is observed as concentrated puncta spreading from cells and forming bridge-like structures. It is noteworthy that Pg immunostaining was concentrated around the blood vessels throughout the brain tissue (Fig. 2,E), where this protein or its fragments could interact with endotheliocytes.

To check the hypothesis whether astrocytes could be involved in angiostatin production, such cells isolated from the rat brain were incubated with Pg. As it is seen in Fig. 3, after 9-10 days of the primary cultures incubation, more than $95 \%$ of cells were positive for GFAP, the astrocyte-specific marker, and exhibited all morphological features typical of astrocytes.

Immunoblotting of cell lysates from primary cultures of rat astrocytes with using polyclonal antibodies raised against rat Pg is shown in Fig. 4. The lysates of astrocytes contain the large number of immunoreactive polypeptides in the range of apparent molecular masses 92-30 kDa. Predominant double bands 92 and $84 \mathrm{kDa}$ could correspond to native (Glu-) Pg and its partially truncated form (Lys-Pg), which seems to be readily converted into active proteinase Pm on the cellular surface [24]. Polypeptides that migrated at the size of around 65-60 kDa could be products of Pg degradation containing all five kringle domains (K1-5). Several lower molecular mass bands corresponding to approximately $50 \mathrm{kDa}$ (K1-4.5) and $40 \mathrm{kDa}$ (K1-4) angiostatins were also observed. There was an evidence of the presence of detectable bands in the range of $\mathrm{M}_{\mathrm{m}}$ 38-30 $\mathrm{kDa}$. These polypeptides could correspond to distinct glycoforms of K1-3 Pg fragment. It is important to note that polypeptide $35 \mathrm{kDa}$ could be relevant to mini$\mathrm{Pg}$, which is lack of the whole non-catalytic part of proenzyme and activatable to mini-Pm, capable of escaping the action of primary Pm inhibitor, $\alpha 2$ antiplasmin.

During 120 min of incubation of astrocytic primary culture with exogenous Pg, we observed accumulation of several Pg fragments, especially those with approximate $\mathrm{Mm} 60$ and $30 \mathrm{kDa}$, accompanying with the gradual depletion of the both immunoreactive bands of Pg. The obtained results mean that astrocytes are able to produce and/or accumulate Pg

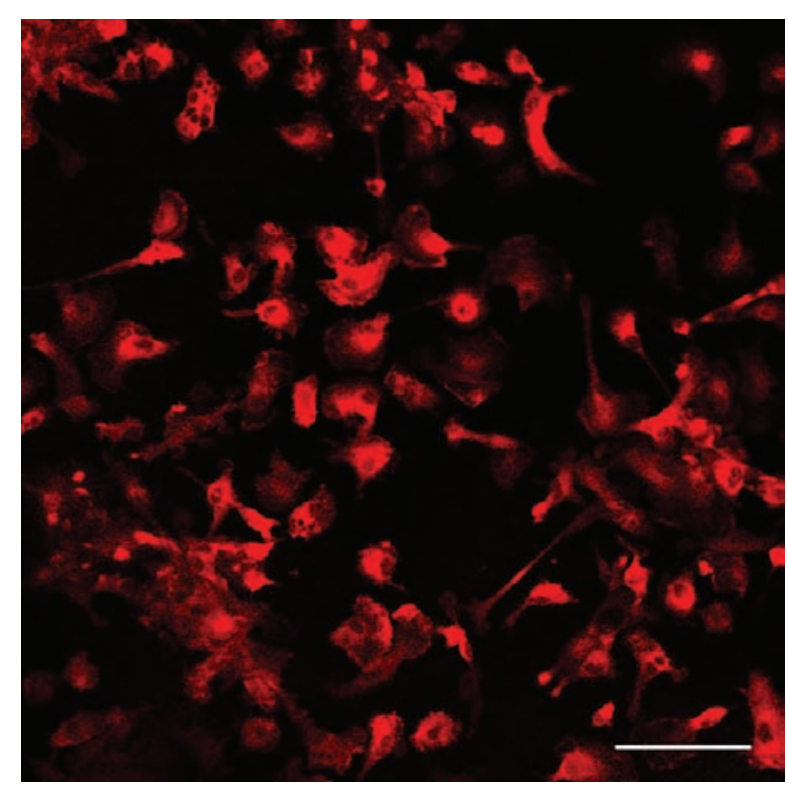

Fig. 3. Primary culture of astrocytes from rat brain (primary anti-GFAP antibodies, secondary AlexaFluor 594-conjugated IgG). Scale bar $=50 \mu \mathrm{m}$

and its fragments and accelerate Pg limited proteolysis.

To check the presence of angiostatin-like polypeptides in conditioned medium of astrocytic primary culture, we analyzed the aliquots of fresh medium before Pg addition ( 0 min point) and repeatedly during $120 \mathrm{~min}$ of incubation. The result of immunoblotting of Pg and its fragments is presented in

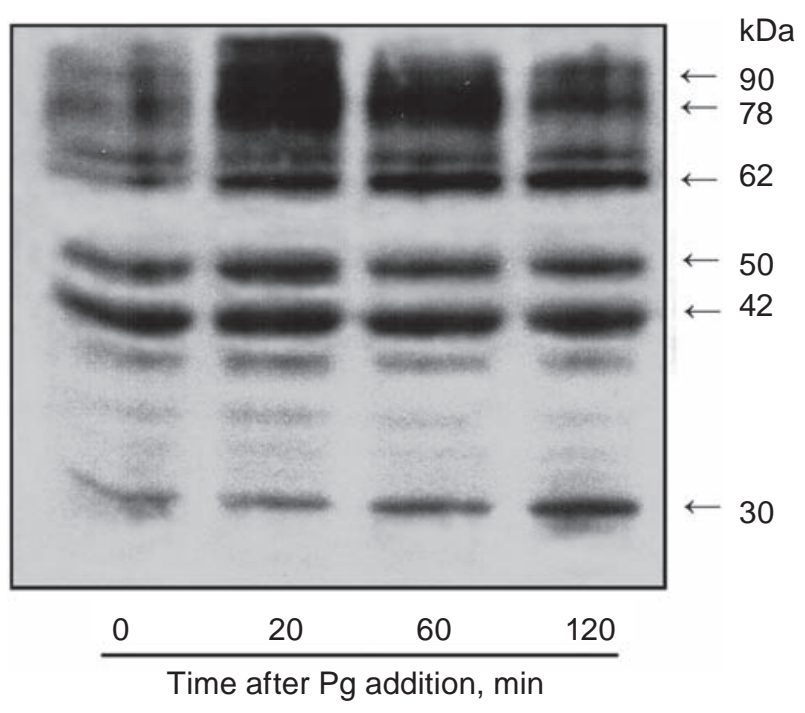

Fig. 4. Representative Western blot of plasminogen and its fragments in astrocyte lysates before (0 min) and after treatment with plasminogen (20-120 min) in vitro 
Fig. 5. Conditioned medium of the primary astrocyte culture per se did not contain any detectable amounts of Pg, while abundance of single $92 \mathrm{kDa}$ was observed in all time points of incubation possibly due to exceeding binding capacity of astrocyte. It is also shown that incubation of astrocytes with Pg resulted in the appearance of the single lower immunoreactive band at approximately $30 \mathrm{kDa}$. The elevation of Pg fragment level was observed within $60 \mathrm{~min}$ of incubation. These results indicate that astrocytes are able not only to accelerate plasminogen fragmentation, but also to release angiostatin-like polypeptides into the extracellular milieu.

For years, Pg has been thought to be primarily a liver-derived protein [25], then the question is how widely Pg may be expressed in other organs, including the brain. Currently, there is an ample body of literature regarding the involvement of $\mathrm{Pg} /$ Pm system in CNS development, normal neural functioning as well as neurologic disorders $[1,2,5]$. Our data expand evidences that rat brain cells are able to produce Pg and are in accordance with the previous reports indicating that Pg is expressed by specific populations of hippocampal, cortical and hypothalamic neurons in murine brain $[13,26]$. Moreover, the available ultrastructural observations demonstrate the vesicular localization of Pg in brain neurons. The authors have revealed numerous Pgimmunoreactive puncta in the somata rather than in the dendrites of hippocampal, cerebral, and hypothalamic neurons, however the way that Pg is released from somatic secretory vesicles currently remains unknown.

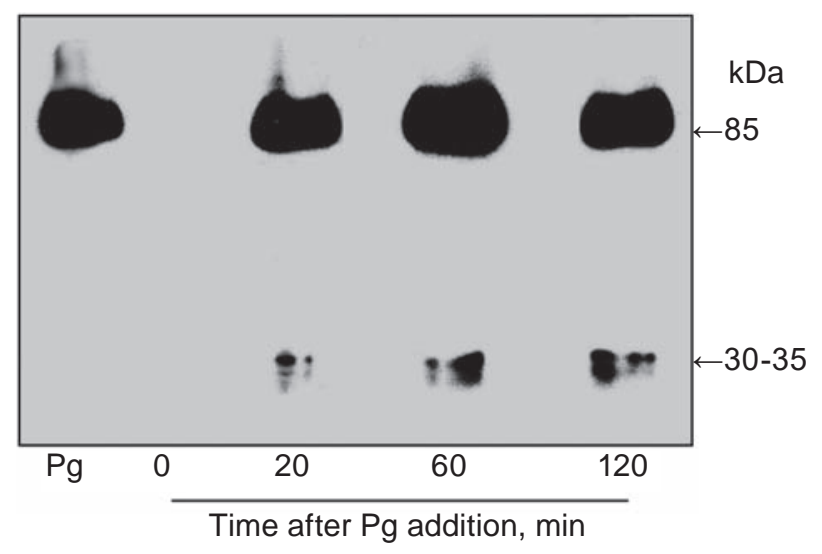

Fig. 5. Representative Western blot of plasminogen and its fragments in the conditioned medium of astrocyte primary culture before (0 $\mathrm{min})$ and after plasminogen addition and treatment for 20-120 min
It has been also shown that Pg displays remarkable structural and functional plasticity, and this determines its physiological function far beyond the fibrinolytic system [1]. In a brain, Pg in concert with its activators, has important functions being involved in neurite outgrowth, neuronal migration, the maintenance of the long-term potentiation (LTP), ocular dominance plasticity, anxiety-like behavior, neuronal degeneration, and blood supply [27]. It is noteworthy that the results of Western blot analysis obtained in our study showed considerable consistency with the results of immunohistochemistry of the brain tissue. The most pronounced Pg-positive immunoreactivity was observed in hippocampal region, the brain region responsible for memory consolidation and learning, where Pg/Pm system can perform specific functions. Indeed, in hippocampal pyramidal neurons, the promotion of the synaptic plasticity and LTP has been demonstrated to be mediated through the cleavage of brain-derived neurotrophic factor (BDNF) by Pm [28]. In the cerebral cortex, we observed Pg immunoreactivity in most of the layers IV, V, and VI. Earlier, it has been shown that proteins of $\mathrm{Pg} / \mathrm{Pm}$ system are directly involved in neurotransmission regulation in active zone of the cerebral cortex. For example, t-PA promotes exocytosis of synaptic vesicles in murine cerebral cortical neurons [29]. Pm can increase the motility of dendritic spines in the visual cortex [30]. The cerebellum is known to play a critical role in many motor and cognitive functions. We have found that Pg expression in the cerebellum occurs in the granule cell and the Purkinje cell layers. Other authors have shown that tPA activity is involved in granule cell migration during development and motor learning in adulthood, and Pg could serve as tPA substrate [31].

So far, exclusive attention has been paid to roles of Pg and its activating system in respect to neuronal functions. Though, it is known that extracellular proteolysis provides an attractive mechanism controlling structural changes and neuronal plasticity in the brain, and products of protein limited digestion of extracellular matrix are believed to play a singificant role in CNS homeostasis and intercellular communications [32]. Among them, angiostatins are major endogenous angiogenesis inhibitors that are generated after serial enzymatic proteolysis of Pg/Pm by multiple enzymatic actions (MMPs, cathepsins, authoproteolysis of Pm) [6]. To our knowledge, studies of angiostatins in the brain tissue have described only effects of angiostatin-encoding genetic con- 
structions in animal models of pathologies. Besides, recent studies have suggested that adeno-associated virus angiostatin vector causes markedly smaller tumors with reduced neovascularization and higher apoptotic indices in C6 glioma cells, when they are propagated intracerebrally and are injected to animals [33]. One of the most significant and novel results of our study is detection of angiostatins in brain tissue, determination of their polypeptide composition and regional distribution. Here, we demonstrate that of all regions studied the cerebral cortex is characterized by the most abundant amounts of angiostatins (mainly, polypeptides with $\mathrm{M}_{\mathrm{m}} \sim 50$ and 40-30 kDa). The findings of different expression patterns of angiostatins allow us to assume that angiostatins have some peculiar functions in this brain region. It is well-documented that angiostatins reduce the proliferation and migration of endothelial cells, inhibit vascular tube formation increases endothelial cell apoptosis, and exhibit angiostatic properties in vivo $[6,7]$. It is possible that angiostatins regulate functioning of brain capillaries and are involved in maintenance of blood-brain barrier integrity. Recently, it has been obviously demonstrated that angiostatins are produced in retina of primates during lifetime and suppress excessive neovascularization of macula, thus maintaining a vascular retinal fovea [10]. The potential pathophysiological significance of these proteins may further attract much attention thanks to the recent observations that spectrum of effects, including reducing inflammatory reactivity, stabilization of vascular remodeling and neuroprotection. It is of interest that angiostatin injected into hippocampus of $A \beta_{1-42}$-treated animals showed a broad significantly attenuated secretion of the pro-angiogenic agent, VEGF in lipopolysaccharide (LPS)-stimulated THP-1 cells [34].

After we had shown the presence of Pg and angiostatins in the rat brain, the next step of the current research was to establish, which cell type had a potential to produce and release angiostatins. In respect of this, astrocytes are of particular interest due to the three reasons: 1) astrocytes are the most frequent cells in the CNS, which emulate the metabolic activity of neurons; 2) astrocytes play a pivotal role as "communicators" between neurons and endotheliocytes; 3) astrocytes have been shown to produce and release several negative regulators of angiogenesis, i.e. endostatins, and have all the necessary proteinase and enzyme cascades to decompose Pg to yield angiostatins $[17,19,20]$. So far, there are no data available on this function of brain astrocytes. In our most recent paper [35], we described the presence of several angiostatin isoforms in the rat retina. Also, we found that angiostatin levels appeared to be lower in retinas of rats with diabetes compared to control animals, and such alteration of antiangiogenic potential could be due to sufficient macroglia reactivity. It is known that as a result of damage to neural tissue, ishemic condition, or some metabolic disorders astrocytes acquire reactive phenotype and display pro-angiogenic activity, probably reflecting compensatory mechanisms [18]. In the healthy retina, astrocytes constanlty release antiangiogenic factors through exocytosis that counteract VEGF-angiogenic stimuli and prevent neovascularization surplus, formation of leaky cappilaries with abnormal structure $[10,36]$. Therefore, the similar event may take place in cerebral cortex, and angiostatins may be involved in regulation of microvasculature behavior in cortical networks and influence microangiogenesis. In support of this hypothesis, it should be noted that astrocytes appeared to be able to release angiostatin $30 \mathrm{kDa}$ during in vitro incubation with Pg. However, astrocytes revealed to bear the enormously heterogenic spectrum of angiostatin-like proteins, which, in turn, could affect astrocytic functions. According to the data of [37], MMP-2 and -9 are most frequently synthesized metalloproteinases in astrocytes. In addition, astrocytes express uPAR/uPA-plasminogen activating cascade [10]. It is worth noting that our data are in agreement with the report of Li [38] indicating that human glioma cell line BT325 can convert purified $\mathrm{Pg}$ to angiostatin-like fragments with molecular masses of 65, 60, and $58 \mathrm{kDa}$. According to their molecular mass, the three fragments comprise kringle domain 1 to kringle domain 5 (K1-5). Moreover, these proteolytic fragments have been shown to specifically inhibit the growth of bovine aortic endothelial cells. Thus, multiple nature of proteinase activities in astrocytic cells contributes to angiostatin's variety and levels as well.

It is obvious that the potential role of CNS cells, others than astrocytes, in angiostatin generation cannot be neglected. For example, microglia produce and release Pg in culture [39], and Pg from microglia in the brain could bind to granule and Purkinje cells to produce the pattern of immunolabeling we report. On the other hand, intracellular and extracellular proteases of microglia contribute to various events in the CNS through both nonspecific and limited proteolysis [40], so the contribution of micro- 
glial and other CNS cells to angiostatin production should be further clarified. Conclusively, given the putative role of angiostatins as well as the increasing awareness of the significance of glia in brain physiology and pathology, the present findings may serve to guide future studies on the role of these components of $\mathrm{Pg} / \mathrm{Pm}$ system in the healthy brain and neuropathologies.

Acknowledgments. The authors have no financial interest or conflict of interest in association with this work. This manuscript has not been published previously and is not considered for publication by another journal. All authors have read and approved the final manuscript. The authors are grateful to Dr. S. A. Karakhim for his excellent technical assistance.

\section{ПЛАЗМІНОГЕН ТА ЙОГО ФРАГМЕНТИ У ГОЛОВНОМУ МОЗКУ ЩУРІВ: МОЖЛИВА РОЛЬ АСТРОЦИТІВ У ГЕНЕРАЦІЇ АНГІОСТАТИНІв}

\author{
A. О. Тихомиров ${ }^{1}$, В. С. Недзвеиький \\ Дж. А. Агджа, В. В. Корса 1 , Т. В. Гриненко \\ ${ }^{1}$ Інститут біохімії ім. О.В. Палладіна \\ НАН України, Київ; \\ ${ }^{2}$ Дніпропетровський національний \\ університет, Дніпро, Україна; \\ ${ }^{3}$ Бінгольський університет, Туреччина; \\ e-mail: artem_tykhomyrov@ukr.net
}

Метою роботи було дослідити локалізацію плазміногену та провести кількісну оцінку його фрагментів (ангіостатинів) у різних відділах головного мозку щурів, а також визначити здатність астроцитів продукувати ангіостатини. За допомогою імуногістохімічного аналізу показано, що плазміноген широко експресується в різних структурах головного мозку, головним чином у менінгеальному шарі, IV, V та VI шаpax кори великих півкуль, зубчастій звивині, клітинах Пуркінє, молекулярному, гранулярному та менінгеальному шарах мозочку. Із застосуванням вестерн-блот аналізу встановлено, що серед усіх досліджуваних відділів мозку ангіостатини в найбільшій кількості містяться в корі великих півкуль і представлені поліпептидами з Мм 50 та 40-30 кДа. У лізатах астроцитів головного мозку, що вирощувалися у вигляді первинної культури, виявлено наявність імунореактивних поліпептидів, які за величиною Мм 92, 84, 65-60, 50, 40, 38-30 кДа відповідають нативному плазміногену та цілій низці продуктів його часткової деградації, включаючи ангіостатини. Інкубація астроцитів 3 ендогенним плазміногеном привела до зростання рівнів деяких фрагментів плазміногену, передусім протеїну 30 кДа. Більш того, вказаний поліпептид виявився єдиним ангіостатином, що вивільняється астроцитами. Отже, у нашому дослідженні вперше продемонстровано, що астроцити є одним із клітинних типів ЦНС, що залучається до утворення ангіостатинів. .

К лючов і с лов а: плазміноген, ангіостатини, головний мозок щура, астроцити, первинна культура, імуногістохімія, вестернблот.

\section{ПЛАЗМИНОГЕН И ЕГО ФРАГМЕНТЫ В ГОЛОВНОМ МОЗГЕ КРЫС: ВОЗМОЖНАЯ РОЛЬ АСТРОЦИТОВ В ГЕНЕРАЦИИ АНГИОСТАТИНОВ}

\author{
А. А. Тихомиров ${ }^{1}$ В. С. Недзвеикий ${ }^{2,3}$, \\ Дж. А. Агджа' , В. В. Корса ${ }^{1}$, Т. В. Гриненко \\ ${ }^{1}$ Институт биохимии им. А. В. Палладина \\ НАН Украины, Киев; \\ ${ }^{2}$ Днепропетровский национальный \\ университет, Днипро, Украина; \\ ${ }^{3}$ Бингольский университет, Турция; \\ e-mail: artem_tykhomyrov@ukr.net
}

Целью представленной работы было изучить локализацию плазминогена и провести количественную оценку его фрагментов (ангиостатинов) в разных отделах головного мозга крыс, а также определить способность астроцитов продуцировать ангиостатины. С помощью иммуногистохимического анализа показано, что плазминоген широко экспрессируется в разных структурах головного мозга, главным образом, в менингеальном слое, IV, V, VI слоях коры больших полушарий, зубчатой извилине, клетках Пуркинье, молекулярном, гранулярном и менингеальном слоях мозжечка. С использованием вестерн-блот анализа установлено, что из всех исследованных отделов мозга ангиостатины в наибольшем количестве содержатся в коре больших полушарий и представлены полипептидами с Мм 50 и 40-30 кДа. В лизатах астроцитов головного мозга, которые выращивались в 
виде первичной культуры, обнаружено наличие иммунореактивных полипептидов, которые по величине Мм 92, 84, 65-60, 50, 40, 38-30 кДа соответствуют нативному плазминогену и целому ряду продуктов его частичной деградации, в том числе ангиостатинам. Инкубация астроцитов с эндогенным плазминогеном привела к увеличению уровня некоторых фрагментов плазминогена, прежде всего протеина 30 кДа. Более того, указанный полипептид оказался единственным ангиостатином, который высвобождается астроцитами. Таким образом, в нашем исследовании впервые продемонстрировано, что астроциты являются одним из клеточных типов ЦНС, который вовлекается в образование ангиостатинов.

К л ю ч е в ы е с ло в а: плазминоген, ангиостатины, головной мозг крысы, астроциты, первичная культура, иммуногистохимия, вестерн-блот.

\section{References}

1. Law RH, Abu-Ssaydeh D, Whisstock JC. New insights into the structure and function of the plasminogen/plasmin system. Curr Opin Struct Biol. 2013; 23(6): 836-841.

2. Melchor JP, Strickland S. Tissue plasminogen activator in central nervous system physiology and pathology. Thromb Haemost. 2005; 93(4): 655-660.

3. Niego B, Freeman R, Puschmann TB, Turnley AM, Medcalf RL. t-PA-specific modulation of a human blood-brain barrier model involves plasmin-mediated activation of the Rho kinase pathway in astrocytes. Blood. 2012; 119(20): 4752-4771.

4. Calabresi P, Napolitano M, Centonze D, Marfia GA, Gubellini P, Teule MA, Berretta N, Bernardi G, Frati L, Tolu M, Gulino A. Tissue plasminogen activator controls multiple forms of synaptic plasticity and memory. Eur J Neurosci. 2000; 12(3): 1002-1012.

5. Silverman MA, Johnson S, Gurkins D, Farmer M, Lochner JE, Rosa P, Scalettar BA. Mechanisms of transport and exocytosis of dense-core granules containing tissue plasminogen activator in developing hippocampal neurons. J Neurosci. 2005; 25(12): 3095-3106.

6. Soff GA. Angiostatin and angiostatin-related proteins. Cancer Metastasis Rev. 2000; 19(1-2): 97-107.
7. Wahl ML, Owen CS, Grant DS. Angiostatin induces intracellular acidosis and anoikis in endothelial cells at a tumor-like low $\mathrm{pH}$. Endothelium. 2002; 9(3): 205-216.

8. Radziwon-Balicka A, Moncada de la Rosa C, Zielnik B, Doroszko A, Jurasz P. Temporal and pharmacological characterization of angiostatin release and generation by human platelets: implications for endothelial cell migration. PLoS One. 2013; 8(3): e59281.

9. van Tilborg AA, Sweep FC, Geurts-Moespot AJ, Wetzels AM, de Waal RM, Westphal JR, Massuger LF. Plasminogen activators are involved in angiostatin generation in vivo in benign and malignant ovarian tumor cyst fluids. Int J Oncol. 2014; 44(4): 1394-1400.

10. Böhm MR, Hodes F, Brockhaus K, Hummel S, Schlatt S, Melkonyan $\mathrm{H}$, Thanos S, et al. Is Angiostatin Involved in Physiological Foveal Avascularity? Invest Ophthalmol Vis Sci. 2016; 57(11): 4536-4552.

11. Liang YZ, Zeng ZL, Hua LL, Li JF, Wang YL, $\mathrm{Bi} \mathrm{XZ}$. Expression and significance of angiostatin, vascular endothelial growth factor and matrix metalloproteinase- 9 in brain tissue of diabetic rats with ischemia reperfusion. Asian Pac J Trop Med. 2016; 9(6): 587-591.

12. Deininger $\mathrm{MH}$, Winkler $\mathrm{S}$, Kremsner $\mathrm{PG}$, Meyermann R, Schluesener HJ. Angiogenic proteins in brains of patients who died with cerebral malaria. J Neuroimmunol. 2003; 142(12): 101-111.

13. Taniguchi $\mathrm{Y}$, Inoue $\mathrm{N}$, Morita S, Nikaido $\mathrm{Y}$, Nakashima T, Nagai N, Okada K, Matsuo O, Miyata S. Localization of plasminogen in mouse hippocampus, cerebral cortex, and hypothalamus. Cell Tissue Res. 2011; 343(2): 303-317.

14. Zhang G, Jin G, Nie X, Mi R, Zhu G, Jia W, Liu F. Enhanced antitumor efficacy of an oncolytic herpes simplex virus expressing an endostatinangiostatin fusion gene in human glioblastoma stem cell xenografts. PLoS One. 2014; 9(4): e95872.

15. Perri SR, Nalbantoglu J, Annabi B, Koty Z, Lejeune L, François M, Di Falco MR, Béliveau R, Galipeau J. Plasminogen kringle 5-engineered glioma cells block migration of tumor-associated macrophages and suppress tumor vascularization and progression. Cancer Res. 2005; 65(18): 8359-8365. 
16. Pekny M, Pekna M, Messing A, Steinhäuser C, Lee JM, Parpura V, Hol EM, Sofroniew MV, Verkhratsky A. Astrocytes: a central element in neurological diseases. Acta Neuropathol. 2016; 131(3): 323-345.

17. Broux B, Gowing E, Prat A. Glial regulation of the blood-brain barrier in health and disease. Semin Immunopathol. 2015; 37(6): 577-590.

18. Argaw AT, Asp L, Zhang J, Navrazhina K, Pham T, Mariani JN, Mahase S, Dutta DJ, Seto J, Kramer EG, Ferrara N, Sofroniew MV, John GR. Astrocyte-derived VEGF-A drives blood-brain barrier disruption in CNS inflammatory disease. J Clin Invest. 2012; 122(7): 2454-2468.

19. Hajrasouliha AR, Jiang G, Lu Q, Lu H, Kaplan HJ, Zhang HG, Shao H. Exosomes from retinal astrocytes contain antiangiogenic components that inhibit laser-induced choroidal neovascularization. J Biol Chem. 2013; 288(39): 28058-28067.

20. Le DM, Besson A, Fogg DK, Choi KS, Waisman DM, Goodyer CG, Rewcastle B, Yong VW. Exploitation of astrocytes by glioma cells to facilitate invasiveness: a mechanism involving matrix metalloproteinase- 2 and the urokinase-type plasminogen activator-plasmin cascade. J Neurosci. 2003; 23(10): 4034-4043.

21. Bermúdez O, Parra A, Ramírez L. Purification and activation of caprine and canine plasminogens: comparison with human plasminogen. IATREIA. 2011; 24(2): 117-125.

22. Stoscheck CM. Quantitation of protein. Methods Enzymol. 1990; 182: 50-68.

23. Abraham S, de Vellis J, Vernadakis A, Haber B. eds. A dissection and tissue culture manual of the nervous system. New York: Alan R. Liss, Inc. 1989.

24. Miles LA, Castellino FJ, Gong Y. Critical role for conversion of glu-plasminogen to Lys-plasminogen for optimal stimulation of plasminogen activation on cell surfaces. Trends Cardiovasc Med. 2003; 13(1): 21-30.

25. Bohmfalk JF, Fuller GM. Plaminogen is synthesized by primary cultures of rat hepatocytes. Science. 1980; 209(4454): 408-410.

26. Basham ME, Seeds NW. Plasminogen expression in the neonatal and adult mouse brain. J Neurochem. 2001; 77(1): 318-325.

27. Yepes M, Lawrence DA. New functions for an old enzyme: nonhemostatic roles for tissue-type plasminogen activator in the central nervous system. Exp Biol Med (Maywood). 2004; 229(11): 1097-1104.

28. Pang PT, Teng HK, Zaitsev E, Woo NT, Sakata K, Zhen S, Teng KK, Yung WH, Hempstead BL, $\mathrm{Lu}$ B. Cleavage of proBDNF by tPA/plasmin is essential for long-term hippocampal plasticity. Science. 20045; 306(5695): 487-491.

29. Wu F, Torre E, Cuellar-Giraldo D, Cheng L, Yi H, Bichler EK, García PS, Yepes M. Tissuetype plasminogen activator triggers the synaptic vesicle cycle in cerebral cortical neurons. J Cereb Blood Flow Metab. 2015; 35(12): 19661976.

30. Oray S, Majewska A, Sur M. Dendritic spine dynamics are regulated by monocular deprivation and extracellular matrix degradation. Neuron. 2004; 44(6): 1021-1030.

31. Li J, Yu L, Gu X, Ma Y, Pasqualini R, Arap W, Snyder EY, Sidman RL. Tissue plasminogen activator regulates Purkinje neuron development and survival. Proc Natl Acad Sci USA. 2013; 110(26): E2410-E2419.

32. Tsilibary E, Tzinia A, Radenovic L, Stamenkovic V, Lebitko T, Mucha M, Pawlak R, Frischknecht R, Kaczmarek L. Neural ECM proteases in learning and synaptic plasticity. Prog Brain Res. 2014; 214: 135-157.

33. Ma HI, Lin SZ, Chiang YH, Li J, Chen SL, Tsao YP, Xiao X. Intratumoral gene therapy of malignant brain tumor in a rat model with angiostatin delivered by adeno-associated viral (AAV) vector. Gene Ther. 2002; 9(1): 2-11.

34. Ryu JK, Little JP, Klegeris A, Jantaratnotai N, McLarnon JG. Actions of the anti-angiogenic compound angiostatin in an animal model of Alzheimer's disease. Curr Alzheimer Res. 2013; 10(3): 252-260.

35. Guzyk MM, Tykhomyrov AA, Nedzvetsky VS, Prischepa IV, Grinenko TV, Yanitska LV, Kuchmerovska TM. Poly(ADP-Ribose) Polymerase-1 (PARP-1) Inhibitors Reduce Reactive Gliosis and Improve Angiostatin Levels in Retina of Diabetic Rats. Neurochem Res. 2016; 41(10): 2526-2537.

36. Pearce JW, Janardhan KS, Caldwell S, Singh B. Angiostatin and integrin alphavbeta3 in the feline, bovine, canine, equine, porcine and murine retina and cornea. Vet Ophthalmol. 2007; 10(5): 313-319.

37. Di Bari G, Gentile E, Latronico T, Corriero G, Fasano A, Nonnis Marzano C, Liuzzi GM. Inhibitory Effect of Aqueous Extracts from 
Marine Sponges on the Activity and Expression of Gelatinases A (MMP-2) and B (MMP-9) in Rat Astrocyte Cultures. PLoS One. 2015; 10(6): e0129322.

38. Li F, Yang J, Liu X, He P, Ji S, Wang J, Han J, Chen N, Yao L. Human glioma cell BT325 expresses a proteinase that converts human plasminogen to kringle 1-5-containing fragments. Biochem Biophys Res Commun. 2000; 278(3): 821-825.
39. Nakajima K, Tsuzaki N, Nagata K, Takemoto N, Kohsaka S. Production and secretion of plasminogen in cultured rat brain microglia. FEBS Lett. 1992; 308(2): 179-182.

40. Nakanishi H. Microglial functions and proteases. Mol Neurobiol. 2003; 27(2): 163-176.

Received 14.12.2016 